\title{
Transmission of Natural Radiation from Soil to Maize Plants and Radiological Hazards Resulting from Consumption in Upper Egypt
}

\author{
Ahmed Mohamed Ahmed Mostafa, Mohamed Amin Mahmoud Uosif, \\ Reda Elsaman ${ }^{*}$ and Elsayed Moustafa \\ Physics Department, Faculty of Sciences, Al-Azhar University, \\ Assiut Branch, 71524 Assiut, Egypt \\ *Corresponding author: reda_m8282@yahoo.com
}

Published online: 25 November 2016

To cite this article: Ahmed Mostafa, A. M. et al. (2016). Transmission of natural radiation from soil to maize plants and radiological hazards resulting from consumption in Upper Egypt. J. Phys. Sci., 27(3), 25-49, http://dx.doi.org/10.21315/jps2016.27.3.3

To link to this article: http://dx.doi.org/10.21315/jps2016.27.3.3

\begin{abstract}
Radioactivity concentrations of natural radionuclides $\left({ }^{226} R a,{ }^{232} T h\right.$ and ${ }^{40} \mathrm{~K}$ ) for some agricultural soil and foodstuff (maize) samples were measured by $\mathrm{NaI}(\mathrm{Tl})$ gamma spectrometer. The average activity concentrations in soil samples are 11 \pm 1 to $37 \pm 3 \mathrm{~Bq} \mathrm{~kg}^{-1}, 7 \pm 0.4$ to $18 \pm 2 \mathrm{~Bq} \mathrm{~kg}^{-1}$, and $101 \pm 6$ to $196 \pm 9 \mathrm{~Bq} \mathrm{~kg}^{-1}$ for ${ }^{226} \mathrm{Ra}_{\text {, }}$

${ }^{232} \mathrm{Th}$ and ${ }^{40} \mathrm{~K}$ respectively. The ranges of average activity concentrations for maize samples, collected from the same soil were found to be $5 \pm 0.6$ to $14 \pm 0.7 \mathrm{~Bq} \mathrm{~kg}^{-1}, 6 \pm 1$ to $11 \pm 1 \mathrm{~Bq} \mathrm{~kg}$ and $154 \pm 8$ to $233.4 \pm 12 \mathrm{~Bq} \mathrm{~kg}^{-1}$ for ${ }^{226} \mathrm{Ra},{ }^{232} \mathrm{Th}$ and ${ }^{40} \mathrm{~K}$ respectively. The transfer factors (TFS) of natural radiation from soil to maize plants were also calculated. Additionally, the radiological hazards for farmers and populations were obtained. The obtained values are comparable to the internationally recommended values. The annual effective dose from maize consumption was also estimated, which was found to be in the range of between 254.4 and $511.5 \mu S v y^{-1}$.
\end{abstract}

Keywords: Natural radionuclides, soil, maize, transfer factor, radiological hazards

\section{INTRODUCTION}

There are many naturally occurring radionuclides in the environment, existing in the soil, sediment, water, plants and air. ${ }^{1}$ The consumption of food is generally the most important route by which natural radionuclides enter the human body. Therefore, it is important to assess the natural radionuclide levels in different foods and diets and to estimate the intake of these radionuclides. ${ }^{2}$ 
The ratio of the radionuclide concentration in plants to the radionuclide concentration in soil per unit mass is referred to as the transfer factor (TF). The TF for a given type of plant and for a given radionuclide can vary considerably from one site to another, depending on several factors such as the chemical and physical properties of the soil, the environmental conditions, and the chemical form of the radionuclide in the soil. ${ }^{3}$

The aim of this study is to measure the concentrations of ${ }^{232} \mathrm{Th},{ }^{226} \mathrm{Ra}$, and ${ }^{40} \mathrm{~K}$, potential radiological hazards for farmers and populations, to provide background data on natural radioactive isotopes for the study region, as well as to quantify the presence of long-lived gamma emitters in maize consumed in EL-Mynia governorate, Egypt to determine a TF for natural radionuclides from soil to maize and estimate annual effective doses to the general public due to this consumption.

\section{EXPERIMENTAL}

\subsection{Study Area}

The geographical area of the EL-Mynia governorate is approximately $32,279 \mathrm{~km}^{2}$ and has a population of approximately 4,481,879. The EL-Mynia governorate is located approximately $225 \mathrm{~km}$ south of Cairo and is one of the important agricultural and industrial regions in Egypt. EL-Mynia is mainly an agricultural governorate, as it includes approximately $6 \%$ of the total agricultural lands in Egypt, producing cotton, wheat, corn and potatoes. ${ }^{4}$ This study covered an area in the EL-Mynia governorate from location M2 (27 $\left.36^{\prime} 9.04^{\prime \prime} \mathrm{N} ; 30^{\circ} 48^{\prime} 12.03^{\prime \prime} \mathrm{E}\right)$ to M9 (2841'52.23" N; 3046'5.14" E).

\subsection{Samples Description}

\subsubsection{Soil}

Forty-one samples of agricultural soil were, collected from 14 different locations, coded by M1 to M14, as shown in Figure 1. Elemental analysis of the soil samples was performed using X-ray fluorescence (XRF) at the Material Testing Laboratory in South Valley University, Egypt. The range values of the major elemental concentrations were as follows: $\mathrm{MgO}(1.9 \%-2.1 \%), \mathrm{Al}_{2} \mathrm{O}_{3}(10.4 \%-$ $13.4 \%), \mathrm{SiO}_{2}(4.1 \%-43.6 \%), \mathrm{K}_{2} \mathrm{O}(1.7 \%-1.9 \%), \mathrm{CaO}(7.3 \%-9.3 \%), \mathrm{TiO}_{2}(3.2 \%-$ $3.7 \%), \mathrm{MnO}(0.6 \%-0.8 \%)$ and $\mathrm{Fe}_{2} \mathrm{O}_{3}(18.4 \%-27.7 \%)$. 


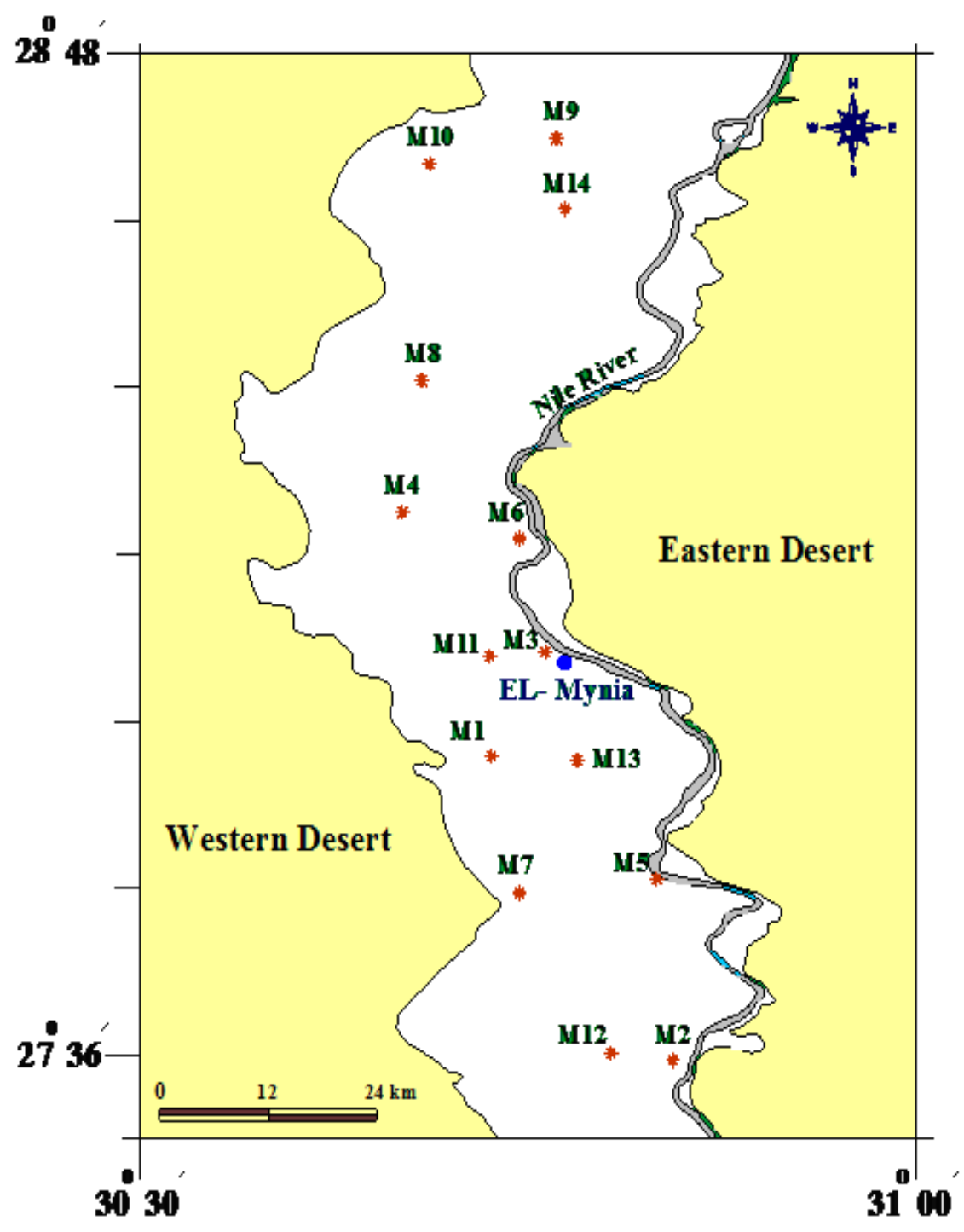

Figure 1: Map of sample locations of the studied area.

The physicochemical characteristics of the agricultural soil under study, such as hydrogen ion $(\mathrm{PH})$, quantity of organic matter and texture of soil, were determined using a PH meter, the Walkley-Black method and the particle size distribution by pipette method, respectively. The hydrogen ion concentration ranged from $7.1-8.1$, the quantity of organic matter ranged from $0.4 \%-2.6 \%$, and the soil texture varied among Sandy Clay Loam, Clay Loam, Silt Clay Loam and Silt Loam. 


\subsubsection{Maize}

Forty-one samples of maize were collected at harvest time from the same locations as the agricultural soil samples. The maize samples studied were of the strains Hitech Triple, Giza 311, Hybrid 314, Giza 101, Hybrid 101, Pioneer and Fine Seeds 101. The maize grains were both white and yellow. The consumption of maize per capita in the study area ${ }^{5}$ is $67.3 \mathrm{~kg} \mathrm{y}^{-1}$.

\subsection{Sampling and Sample Preparation}

Eighty-two samples of soil and maize were collected from 14 locations (M1 to M14), with 3 samples of soil and 3 samples of maize from each location except M14, where 2 samples of soil and 2 samples of maize were collected. Soil samples were collected using a coring tool to a depth of $5 \mathrm{~cm}$ or to the depth of the plough line. ${ }^{6}$ Maize samples were collected at harvest time from the same locations as the agricultural soil samples. All samples were dried in an oven at approximately $110^{\circ} \mathrm{C}$ for $24 \mathrm{~h}$ to ensure that moisture was completely removed, while maize samples were oven dried at $95^{\circ} \mathrm{C}$.

All soil samples were crushed, homogenised, and sieved through a $200-\mu \mathrm{m}$ sieve, which is the optimum size for particles enriched in heavy minerals. Samples were placed in polyethylene beakers, $250 \mathrm{~cm}^{3}$ each, and weighed. The beakers were completely sealed for 4 weeks to reach secular equilibrium for radium and thorium and their progenies. ${ }^{7}$

\subsection{Instrumentation and Calibration}

Radioactivity measurements were performed by gamma ray spectrometer, employing a high-resolution scintillation detector $\mathrm{NaI}(\mathrm{Tl})$ crystal $3 \times 3$ inch. It had a hermetically sealed assembly including a $\mathrm{NaI}$ (Tl) crystal coupled with a PC-MCA Canberra Accuspec (US).

To reduce the gamma-ray background, a cylindrical lead shield (100 mm thick) with a fixed bottom and movable cover was used to shield the detector. The lead shield contained an inner concentric cylinder of copper ( $0.3 \mathrm{~mm}$ thick) to absorb X-rays generated in the lead. ${ }^{8}$

To determine the background distribution in the environment around the detector, an empty sealed beaker was counted in the same manner and in the same geometry as the samples. The measurement time of the activity or background was $43,200 \mathrm{~s}$. The background spectra were used to correct the net peak area of 
the gamma rays of the measured isotopes. The dedicated software program Genie- $000^{9}$ was used.

The detection array was energy-calibrated using ${ }^{60} \mathrm{Co}(1173.2$ and $1332.5 \mathrm{keV})$, ${ }^{133} \mathrm{Ba}(356.1 \mathrm{keV})$ and ${ }^{137} \mathrm{Cs}(661.9 \mathrm{keV})$. The efficiency calibration curve was constructed using different energy peaks covering the range up to $\sim 2000 \mathrm{keV}$. Efficiency and energy calibrations for each sample measurement were performed to maintain the quality of the measurements. For quality control, the uncertainties of the measured values have been calculated from all parameters. All procedures are described in previous publications. ${ }^{10}$

The lower limit of detection (LLD) was calculated according to the IAEA directions ${ }^{6}$ and is given by Equation 1:

$$
L L D=\frac{4.66 \sqrt{F_{c}}}{\varepsilon \cdot P_{\gamma} \cdot m \cdot t}
$$

where

$\mathrm{F}_{\mathrm{c}}=$ the Compton background in the region of the selected gamma line in the sample spectrum, $\varepsilon=$ the system detection efficiency, $\mathrm{P}_{\gamma}=$ the absolute transition probability by gamma decay, $\mathrm{m}=$ the sample mass in kilograms, and $\mathrm{t}=$ the counting time in seconds.

The lower limit of detection (LLD) in the case of soil samples was 2.4, 1.4 and 5.8 and for maize grains was $1.2,1.3$ and $5\left(\mathrm{~Bq} \mathrm{~kg}^{-1}\right)$ for ${ }^{226} \mathrm{Ra},{ }^{232} \mathrm{Th}$ and ${ }^{40} \mathrm{~K}$, respectively.

Figure 2 presents an example of the energy spectra, indicating the gamma-ray lines of different origin compared with the background for soil. 


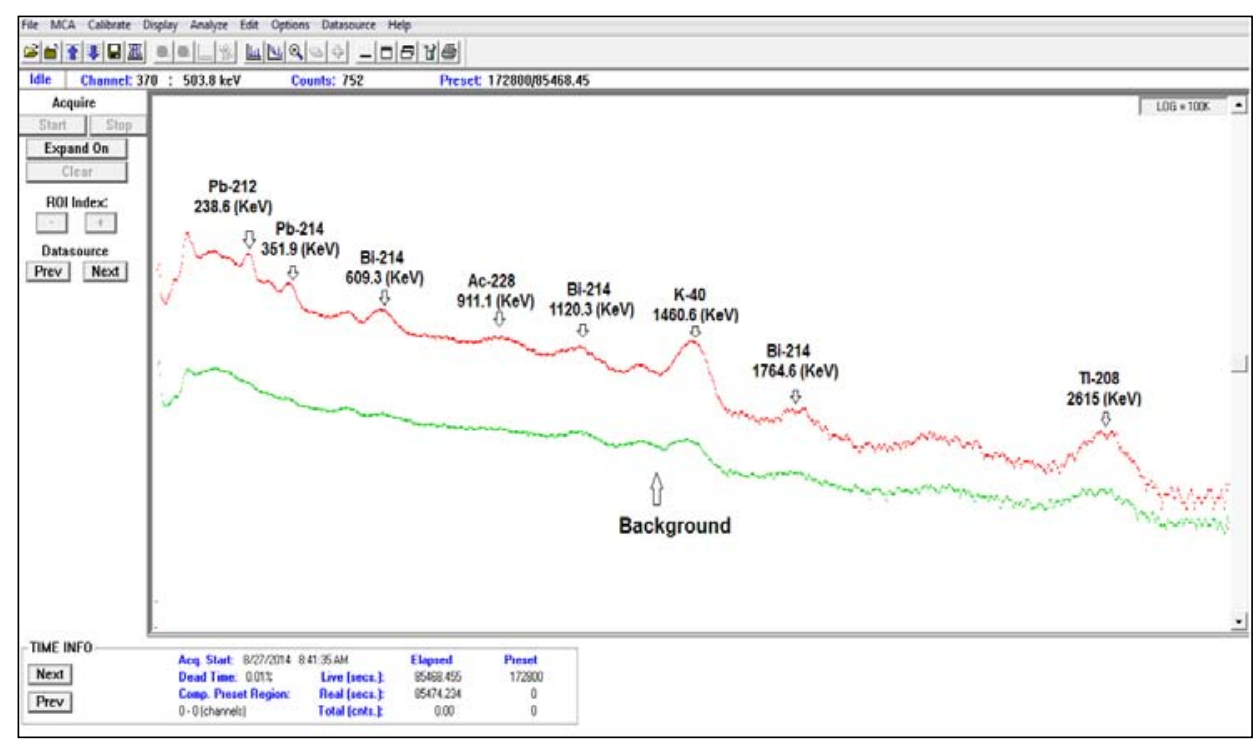

Figure 2: Typical gamma-ray lines spectrum of soil sample and background.

\section{RESULTS AND DISCUSSION}

\subsection{Natural Radioactivity}

\subsubsection{Soil}

The concentrations of ${ }^{226} \mathrm{Ra},{ }^{232} \mathrm{Th}$, and ${ }^{40} \mathrm{~K}$ in the collected samples of agricultural soil are listed in Table 1. The average values of the activity concentrations in soil varied from $11 \pm 1$ to $37 \pm 3 \mathrm{~Bq} \mathrm{~kg}^{-1}$, from $7 \pm 0.4$ to $18 \pm 2$ $\mathrm{Bq} \mathrm{kg}{ }^{-1}$, and from $101 \pm 6$ to $196 \pm 9 \mathrm{~Bq} \mathrm{~kg}^{-1}$ for ${ }^{226} \mathrm{Ra},{ }^{232} \mathrm{Th}$ and ${ }^{40} \mathrm{~K}$, respectively.

The variation in soils from different locations may be attributed to the wide variations in the geological formation of different types of soil. The higher ${ }^{40} \mathrm{~K}$ activity concentrations compared with ${ }^{226} \mathrm{Ra}$ and ${ }^{232} \mathrm{Th}$ may be due to the widespread use of fertilisers. ${ }^{11}$

These data show that the activity concentrations of ${ }^{226} \mathrm{Ra},{ }^{232} \mathrm{Th}$ and ${ }^{40} \mathrm{~K}$ in the soil samples were below the world averages of 35,35 and $370 \mathrm{~Bq} \mathrm{~kg}{ }^{-1}$ for ${ }^{226} \mathrm{Ra}$, ${ }^{232} \mathrm{Th}$ and ${ }^{40} \mathrm{~K}$, respectively, ${ }^{12}$ except for the ${ }^{226} \mathrm{Ra}$ activity concentration $\left(37 \pm 3 \mathrm{~Bq} \mathrm{~kg}^{-1}\right)$ in the samples from location M12. 


\subsubsection{Maize grain samples}

The mean activities of the measured radionuclides in the 41 maize samples are given in Table 1. The results show that the mean activities of ${ }^{226} \mathrm{Ra}$ ranged from 5 \pm 0.6 to $14 \pm 0.7 \mathrm{~Bq} \mathrm{~kg}^{-1}$, while the mean activities of ${ }^{232} \mathrm{Th}$ ranged from $5 \pm 0.3$ to $11 \pm 1 \mathrm{~Bq} \mathrm{~kg}^{-1}$. Finally, the ${ }^{40} \mathrm{~K}$ concentrations ranged from $154 \pm 8$ to $233.4 \pm$ $12 \mathrm{~Bq} \mathrm{~kg}$. Thus, ${ }^{40} \mathrm{~K}$ showed the highest values among the maize samples despite having the lowest activity concentrations in the soil samples.

Table 1: Average activity concentrations $\left(\mathrm{Bq} \mathrm{kg}^{-1}\right.$ ) of ${ }^{226} \mathrm{Ra},{ }^{232} \mathrm{Th}$ and ${ }^{40} \mathrm{~K}$ in agricultural soil and maize.

\begin{tabular}{|c|c|c|c|c|c|c|}
\hline \multirow{2}{*}{$\begin{array}{l}\text { Location } \\
\text { code }\end{array}$} & \multicolumn{3}{|c|}{ Activity in soil $\left(\mathrm{Bq} \mathrm{kg}^{-1}\right)$} & \multicolumn{3}{|c|}{ Activity in maize $\left(\mathrm{Bq} \mathrm{kg}^{-1}\right)$} \\
\hline & ${ }^{226} \mathrm{Ra}$ & ${ }^{232} \mathrm{Th}$ & ${ }^{40} \mathrm{~K}$ & ${ }^{226} \mathrm{Ra}$ & ${ }^{232} \mathrm{Th}$ & ${ }^{40} \mathrm{~K}$ \\
\hline M1 & $\begin{array}{c}22 \pm 1^{*} \\
(17-27)\end{array}$ & $\begin{array}{l}10 \pm 0.5 \\
(7-11)\end{array}$ & $\begin{array}{c}149 \pm 7 \\
(128-160)\end{array}$ & $\begin{array}{l}5 \pm 0.6 \\
(3-8)\end{array}$ & $\begin{array}{c}6 \pm 1 \\
(3-10)\end{array}$ & $\begin{array}{c}154 \pm 8 \\
(116-201)\end{array}$ \\
\hline M2 & $\begin{array}{c}13 \pm 0.7 \\
(11-15)\end{array}$ & $\begin{array}{l}11 \pm 0.6 \\
(9-12)\end{array}$ & $\begin{array}{c}174 \pm 10 \\
(178-190)\end{array}$ & $\begin{array}{c}10 \pm 2 \\
(8-11)\end{array}$ & $\begin{array}{c}9 \pm 2 \\
(8-11)\end{array}$ & $\begin{array}{c}177 \pm 9 \\
(147-192)\end{array}$ \\
\hline M3 & $\begin{array}{c}28 \pm 2 \\
(22-35)\end{array}$ & $\begin{array}{c}18 \pm 2 \\
(14-21)\end{array}$ & $\begin{array}{c}168 \pm 8 \\
(164-174)\end{array}$ & $\begin{array}{c}12 \pm 0.6 \\
(10-13)\end{array}$ & $\begin{array}{l}6 \pm 0.5 \\
(5-7)\end{array}$ & $\begin{array}{c}208 \pm 11 \\
(151-245)\end{array}$ \\
\hline M4 & $\begin{array}{c}30 \pm 2 \\
(20-37)\end{array}$ & $\begin{array}{c}16 \pm 0.9 \\
(15-19)\end{array}$ & $\begin{array}{c}165 \pm 8 \\
(162-167)\end{array}$ & $\begin{array}{c}11 \pm 1 \\
(7-14)\end{array}$ & $\begin{array}{c}9 \pm 1 \\
(7-11)\end{array}$ & $\begin{array}{c}215 \pm 11 \\
(205-227)\end{array}$ \\
\hline M5 & $\begin{array}{c}23 \pm 1 \\
(15-30)\end{array}$ & $\begin{array}{c}13 \pm 0.6 \\
(11-15)\end{array}$ & $\begin{array}{c}165 \pm 8 \\
(161-168)\end{array}$ & $\begin{array}{c}9 \pm 3 \\
(8-9)\end{array}$ & $\begin{array}{c}10 \pm 2 \\
(7-11)\end{array}$ & $\begin{array}{c}182 \pm 10 \\
(159-198)\end{array}$ \\
\hline M6 & $\begin{array}{c}23 \pm 2 \\
(18-31)\end{array}$ & $\begin{array}{l}11 \pm 0.6 \\
(9-13)\end{array}$ & $\begin{array}{c}146 \pm 7 \\
(133-156)\end{array}$ & $\begin{array}{c}12 \pm 1 \\
(9-15)\end{array}$ & $\begin{array}{l}5 \pm 0.3 \\
(3-7)\end{array}$ & $\begin{array}{c}208 \pm 10 \\
(178-205)\end{array}$ \\
\hline M7 & $\begin{array}{c}13 \pm 0.7 \\
(11-15)\end{array}$ & $\begin{array}{l}11 \pm 0.6 \\
(9-12)\end{array}$ & $\begin{array}{c}177 \pm 10 \\
(162-190)\end{array}$ & $\begin{array}{l}11 \pm 0.8 \\
(9-13)\end{array}$ & $\begin{array}{c}8 \pm 0.7 \\
(7-10)\end{array}$ & $\begin{array}{c}215 \pm 12 \\
(196-236)\end{array}$ \\
\hline M8 & $\begin{array}{c}20 \pm 2 \\
(12-31)\end{array}$ & $\begin{array}{l}11 \pm 0.6 \\
(8-13)\end{array}$ & $\begin{array}{c}153 \pm 8 \\
(150-158)\end{array}$ & $\begin{array}{c}8 \pm 0.5 \\
(6-10)\end{array}$ & $\begin{array}{l}6 \pm 0.4 \\
(5-8)\end{array}$ & $\begin{array}{c}171 \pm 8 \\
(141-187)\end{array}$ \\
\hline M9 & $\begin{array}{c}11 \pm 1 \\
(9-12)\end{array}$ & $\begin{array}{l}7 \pm 0.4 \\
(6-8)\end{array}$ & $\begin{array}{c}101 \pm 6 \\
(92-112)\end{array}$ & $\begin{array}{c}8 \pm 0.6 \\
(6-10)\end{array}$ & $\begin{array}{c}8.3 \pm 1 \\
(5-12)\end{array}$ & $\begin{array}{c}233 \pm 12 \\
(213-268)\end{array}$ \\
\hline M10 & $\begin{array}{c}16 \pm 1 \\
(12-21)\end{array}$ & $\begin{array}{l}12 \pm 0.5 \\
(9-15)\end{array}$ & $\begin{array}{c}127 \pm 8 \\
(106-146)\end{array}$ & $\begin{array}{l}10 \pm 1.5 \\
(8-12)\end{array}$ & $\begin{array}{c}10 \pm 2 \\
(7-15)\end{array}$ & $\begin{array}{c}213 \pm 11 \\
(210-216)\end{array}$ \\
\hline M11 & $\begin{array}{c}23 \pm 1 \\
(17-29)\end{array}$ & $\begin{array}{l}11 \pm 0.7 \\
(9-13)\end{array}$ & $\begin{array}{c}154 \pm 8 \\
(140-164)\end{array}$ & $\begin{array}{c}14 \pm 0.7 \\
(11-16)\end{array}$ & $\begin{array}{c}11 \pm 1 \\
(10-12)\end{array}$ & $\begin{array}{c}199 \pm 9 \\
(167-226)\end{array}$ \\
\hline M12 & $\begin{array}{c}37 \pm 3 \\
(33-39)\end{array}$ & $\begin{array}{c}16 \pm 1 \\
(13-18)\end{array}$ & $\begin{array}{c}141 \pm 8 \\
(131-157)\end{array}$ & $\begin{array}{c}12 \pm 0.7 \\
(10-14)\end{array}$ & $\begin{array}{c}8 \pm 0.6 \\
6-9\end{array}$ & $\begin{array}{c}164 \pm 8 \\
(156-176)\end{array}$ \\
\hline M13 & $\begin{array}{c}17 \pm 0.9 \\
(13-24)\end{array}$ & $\begin{array}{l}10 \pm 0.6 \\
(5-18)\end{array}$ & $\begin{array}{c}157 \pm 8 \\
(150-166)\end{array}$ & $\begin{array}{l}10 \pm 0.8 \\
(9-10)\end{array}$ & $\begin{array}{l}6 \pm 0.5 \\
(4-7)\end{array}$ & $\begin{array}{c}174 \pm 10 \\
(141-192)\end{array}$ \\
\hline M14 & $\begin{array}{c}21 \pm 1 \\
(17-25)\end{array}$ & $\begin{array}{c}14 \pm 0.7 \\
(12-15)\end{array}$ & $\begin{array}{c}196 \pm 9 \\
(190-201)\end{array}$ & $\begin{array}{c}13 \pm 2 \\
(10-15)\end{array}$ & $\begin{array}{c}9 \pm 1 \\
(8-9)\end{array}$ & $\begin{array}{c}202 \pm 10 \\
(182-222)\end{array}$ \\
\hline
\end{tabular}

${ }^{*}$ Mean \pm uncertainty, (range) 
This result may be attributed in part to the heavy use of chemical fertilisers to improve crop yields on the farms in the area. ${ }^{13}$ In addition, ${ }^{40} \mathrm{~K}$ activities tend to decrease in the deep layers of agricultural soil. The decrease in ${ }^{40} \mathrm{~K}$ with depth is due to the effect of irrigation water in dissolving thorium and potassium compounds. The solutions move towards the surface under the effect of heating by the sun and are deposited by evaporation. ${ }^{14}$

\subsection{TFs for Natural Radioactivity}

TFs were calculated as the ratio of the radionuclide concentration in plants $(\mathrm{Bq}$ $\mathrm{kg}^{-1}$ plant) to the concentration in the soil $\left(\mathrm{Bq} \mathrm{kg}^{-1}\right.$ soil), as shown in Equation 2:

$$
\mathrm{TF}=\mathrm{P} / \mathrm{S}
$$

where

$\mathrm{P}=$ the radionuclide concentration in maize grains $\left(\mathrm{Bq} \mathrm{kg}^{-1}\right.$ dry wt.)

$\mathrm{S}=$ the corresponding concentration in soil ( $\mathrm{Bq} \mathrm{kg}^{-1}$ dry wt.).

The soil to maize grain TFs for the radionuclides studied are given in Table 2 and compared with the default values of $0.04,0.05$ and 1 for ${ }^{226} \mathrm{Ra},{ }^{232} \mathrm{Th}$ and ${ }^{40} \mathrm{~K}$, respectively. ${ }^{15}$ Figures 3, 4 and 5 show the average values of the ${ }^{226} \mathrm{Ra},{ }^{232} \mathrm{Th}$ and ${ }^{40} \mathrm{~K}$ activity concentrations $\left(\mathrm{Bq} \mathrm{kg}{ }^{-1}\right.$ ) in soil and maize and the TFs from soil to maize.

Table 2: Soil to maize transfer factors.

\begin{tabular}{cccc}
\hline \multirow{2}{*}{ Location code } & \multicolumn{3}{c}{ Transfer factor } \\
\cline { 2 - 4 } & ${ }^{226} \mathrm{Ra}$ & ${ }^{232} \mathrm{Th}$ & ${ }^{40} \mathrm{~K}$ \\
\hline \multirow{2}{*}{ M1 } & $0.23^{*}$ & 0.60 & 1.03 \\
& $(0.18-0.30)$ & $(0.27-0.91)$ & $(0.73-1.57)$ \\
M2 & 0.77 & 0.82 & 1.02 \\
& $(0.53-1)$ & $(0.73-0.89)$ & $(0.83-1.2)$ \\
M3 & 0.43 & 0.33 & 1.24 \\
& $(0.37-0.48)$ & $(0.26-0.43)$ & $(0.9-1.49)$ \\
M4 & 0.37 & 0.56 & 1.3 \\
& $(0.32-0.41)$ & $(0.47-0.73)$ & $(1.23-1.37)$ \\
M5 & 0.39 & 0.77 & 1.1 \\
& $(0.3-0.53)$ & $(0.47-1)$ & $(0.96-1.23)$ \\
M6 & 0.52 & 0.45 & 1.42 \\
& $(0.29-0.71)$ & $(0.27-0.77)$ & $(1.19-1.43)$ \\
\hline
\end{tabular}

(continued on next page) 
Table 2: (Continued)

\begin{tabular}{cccc}
\hline M7 & 0.85 & 0.73 & 1.21 \\
& $(0.6-0.93)$ & $(0.64-0.83)$ & $(1.13-1.33)$ \\
M8 & 0.4 & 0.55 & 1.12 \\
& $(0.26-0.83)$ & $(0.46-0.63)$ & $(0.93-1.24)$ \\
M9 & 0.73 & 1.19 & 2.31 \\
& $(0.5-1.11)$ & $(0.63-2)$ & $(1.9-2.73)$ \\
M10 & 0.63 & 0.83 & 1.68 \\
& $(0.38-1)$ & $(0.58-1.67)$ & $(1.47-1.98)$ \\
M11 & 0.61 & 0.97 & 1.29 \\
& $(0.38-0.94)$ & $(0.83-1.33)$ & $(1.02-1.46)$ \\
M12 & 0.32 & 0.50 & 1.16 \\
& $(0.28-0.37)$ & $(0.33-0.69)$ & $(1.02-1.31)$ \\
M13 & 0.59 & 0.6 & 1.11 \\
& $(0.38-0.77)$ & $(0.22-1.2)$ & $(0.91-1.27)$ \\
M14 & 0.62 & 0.64 & 1.03 \\
& $(0.4-0.88)$ & $(0.6-0.67)$ & $(0.91-1.17)$ \\
\hline
\end{tabular}

* Mean, (range)

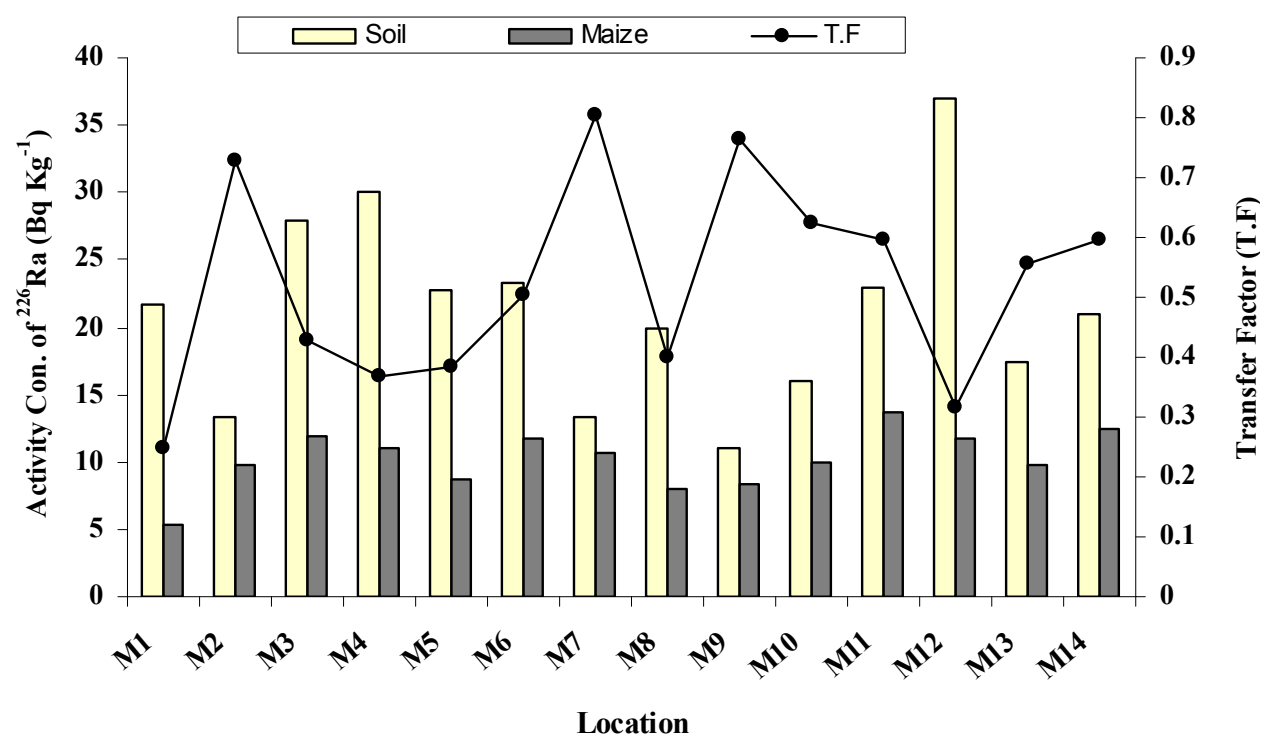

Figure 3: Average values of ${ }^{226} \mathrm{Ra}$ activity concentration $\left(\mathrm{Bq} \mathrm{kg}^{-1}\right)$ in agricultural soil, maize and TF from soil to maize. 


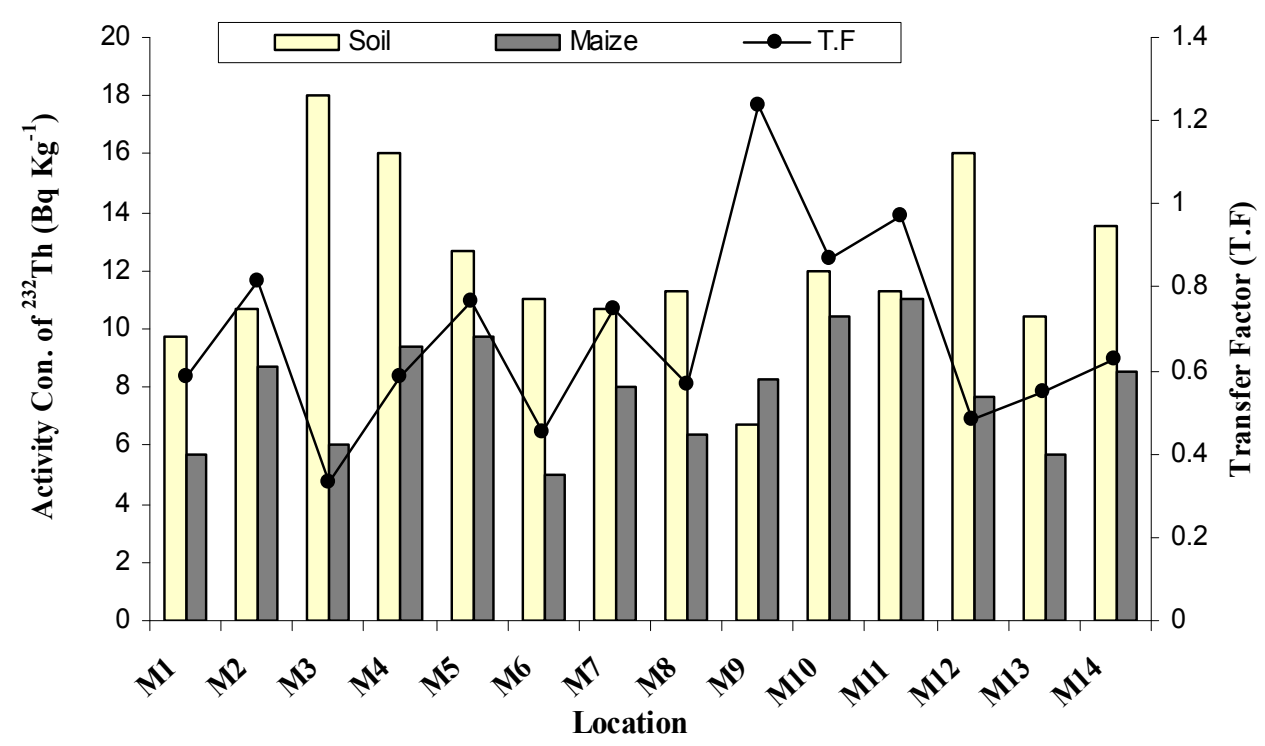

Figure 4: Average values of ${ }^{232} \mathrm{Th}$ activity concentration $\left(\mathrm{Bq} \mathrm{kg}^{-1}\right)$ in agricultural soil, maize and TF from soil to maize.

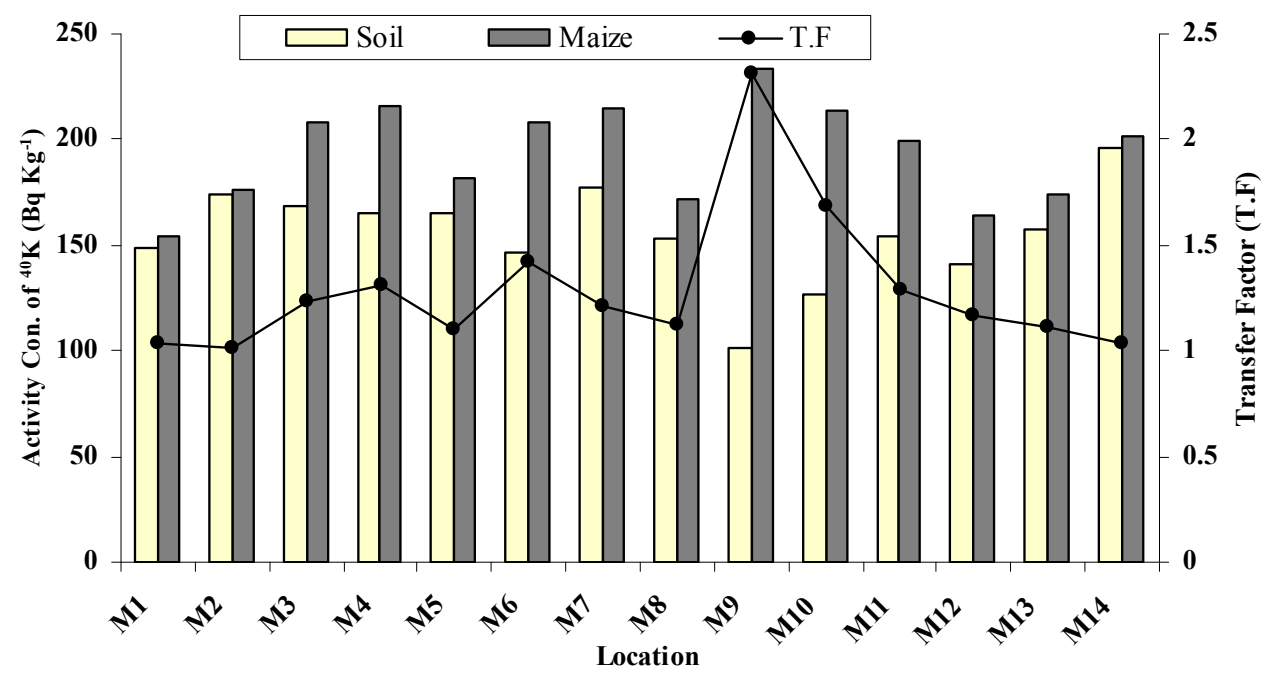

Figure 5 Average values of ${ }^{40} \mathrm{~K}$ activity concentrations $\left(\mathrm{Bq} \mathrm{kg}^{-1}\right)$ in agricultural soil, maize and TF from soil to maize. 


\subsection{Radiological Hazards for Soil}

\subsubsection{Radium equivalent $\left(R_{\mathrm{eq}}\right)$}

The radium equivalent activity was used to obtain the sum of activities to compare the activity concentrations of the soil samples, which contain ${ }^{226} \mathrm{Ra}$, ${ }^{232} \mathrm{Th}$ and ${ }^{40} \mathrm{~K}$. The radium equivalent activities $\left(\mathrm{Ra}_{\mathrm{eq}}\right)$ were calculated based on the estimations that $370 \mathrm{~Bq} \mathrm{~kg}$ of ${ }^{226} \mathrm{Ra}, 259 \mathrm{~Bq} \mathrm{~kg}^{-1}$ of ${ }^{232} \mathrm{Th}$ and $4810 \mathrm{~Bq} \mathrm{~kg}$ of ${ }^{40} \mathrm{~K}$ produce the same gamma ray dose rate; therefore the $\mathrm{Ra}_{\mathrm{eq}}$ is given by: ${ }^{16}$

$$
\mathrm{Ra}_{\mathrm{eq}}=\mathrm{A}_{\mathrm{Ra}}+1.43 \mathrm{~A}_{\mathrm{Th}}+0.077 \mathrm{~A}_{\mathrm{k}}
$$

where $A_{R a}, A_{T h}$ and $A_{K}$ are the activities of ${ }^{226} \mathrm{Ra},{ }^{232} \mathrm{Th}$ and ${ }^{40} \mathrm{~K}$, respectively, in $\mathrm{Bq} \mathrm{kg}{ }^{-1}$. Column 2 of Table 3 gives the radium equivalent activities $\left(\mathrm{Ra}_{\mathrm{eq}}\right)$ for agricultural soil.

Table 3: The equivalent radium $\left(\mathrm{Ra}_{\mathrm{eq}}\right)$, dose rate, annual effective dose (AED), external hazard $\left(\mathrm{H}_{\mathrm{ex}}\right)$ and internal hazard $\left(\mathrm{H}_{\mathrm{in}}\right)$ for agricultural soil.

\begin{tabular}{cccccc}
\hline \multirow{2}{*}{$\begin{array}{c}\text { Location } \\
\text { code }\end{array}$} & $\mathrm{Ra}_{\mathrm{eq}}$ & Dose rate & $(\mathrm{AED})$ & & $\mathrm{H}_{\mathrm{ex}}$ \\
\cline { 2 - 4 } & $\left(\mathrm{Bq} \mathrm{kg}^{-1}\right)$ & $\left(\mathrm{nGy} \mathrm{h}^{-1}\right)$ & $\left(\mu \mathrm{Sv} \mathrm{y}^{-1}\right)$ & & $\mathrm{H}_{\mathrm{in}}$ \\
\hline M1 & $47^{*}$ & 21.9 & 26.9 & 0.127 & 0.186 \\
& $(43-52)$ & $(20.5-23.9)$ & $(25-29.4)$ & $(0.116-0.140)$ & $(0.171-0.213)$ \\
M2 & 48.5 & 22.4 & 27.4 & 0.131 & 0.184 \\
& $(38.1-61)$ & $(17.8-27.5)$ & $(21.9-33.7)$ & $(0.103-0.165)$ & $(0.142-0.228)$ \\
M3 & 66.7 & 30.5 & 37.4 & 0.18 & 0.256 \\
& $(59-75.5)$ & $(27.2-34.5)$ & $(33.4-42.3)$ & $(0.159-0.204)$ & $(0.232-0.299)$ \\
M4 & 66.7 & 30.5 & 37.5 & 0.180 & 0.262 \\
& $(54.7-76.9)$ & $(25.2-35)$ & $(30.9-42.9)$ & $(0.148-0.208)$ & $(0.202-0.308)$ \\
M5 & 53.5 & 24.8 & 30.4 & 0.144 & 0.205 \\
& $(43.4-64.6)$ & $(20.3-29.7)$ & $(24.9-36.4)$ & $(0.117-0.175)$ & $(0.158-0.2560$ \\
M6 & 50.5 & 23.4 & 28.7 & 0.137 & 0.20 \\
& $(43.9-60.6)$ & $(20.3-27.9)$ & $(24.9-34.2)$ & $(0.119-0.164)$ & $(0.167-0.248)$ \\
M7 & 42.3 & 19.9 & 24.4 & 0.114 & 0.151 \\
& $(39.7-46.8)$ & $(18.7-22)$ & $(22.9-27)$ & $(0.107-0.126)$ & $(0.140-0.168)$ \\
M8 & 47.9 & 22.3 & 27.3 & 0.130 & 0.183 \\
& $(35.2-61.3)$ & $(16.6-28.2)$ & $(20.4-34.6)$ & $(0.095-0.166)$ & $(0.127-0.249)$ \\
M9 & 28.4 & 13.3 & 16.3 & 0.076 & 0.106 \\
& $(26.8-30)$ & $(12.5-13.1)$ & $(15.4-17.3)$ & $(0.072-0.081)$ & $(0.100-0.114)$ \\
M10 & 40.3 & 18.6 & 22.9 & 0.109 & 0.152 \\
& $(35.3-47.3)$ & $(16.5-26.4)$ & $(20.3-26.4)$ & $(0.095-0.128)$ & $(0.128-0.186)$ \\
\hline
\end{tabular}


Table 3: (Continued)

\begin{tabular}{cccccc}
\hline M11 & 50.7 & 23.5 & 29 & 0.136 & 0.199 \\
& $(42.2-66.6)$ & $(19.7-30.7)$ & $(24.2-37.7)$ & $(0.114-0.180)$ & $(0.153-0.277)$ \\
M12 & 70 & 31.9 & 39.2 & 0.189 & 0.288 \\
& $(68.1-73.3)$ & $(31.1-33.2)$ & $(38.2-40.8)$ & $(0.184-0.198)$ & $(0.275-0.300)$ \\
M13 & 43.9 & 20.6 & 25.2 & 0.118 & 0.165 \\
& $(37.8-50.9)$ & $(17.9-23.3)$ & $(21.9-28.5)$ & $(0.102-0.137)$ & $(0.142-0.181)$ \\
M14 & 56.5 & 26.4 & 32.4 & 0.153 & 0.21 \\
& $(54.7-58.3)$ & $(25.4-27.3)$ & $(31.2-33.5)$ & $(0.148-0.158)$ & $(0.194-0.226)$ \\
\hline
\end{tabular}

${ }^{*}$ Mean, (range)

From Table 3, we can observe that the radium equivalent values in the agricultural soil samples range from $28.4 \mathrm{~Bq} \mathrm{~kg}^{-1}$ in the samples from location M9 to $70 \mathrm{~Bq} \mathrm{~kg}^{-1}$ in the samples from location M12. These values are lower than the allowed maximum value ${ }^{17}$ of $370 \mathrm{~Bq} \mathrm{~kg}^{-1}$.

As shown in Figure 6, the radium equivalent activity $\mathrm{Ra}_{\mathrm{eq}}$ is heightened in locations M3, M4 and M12, possibly due to the use of chemical fertilisers (mixed fertiliser and single super phosphate). Figure 7 shows the relative contributions of ${ }^{226} \mathrm{Ra},{ }^{232} \mathrm{Th}$ and ${ }^{40} \mathrm{~K}$ to $\mathrm{Ra}_{\mathrm{eq}}$ in agricultural soil.

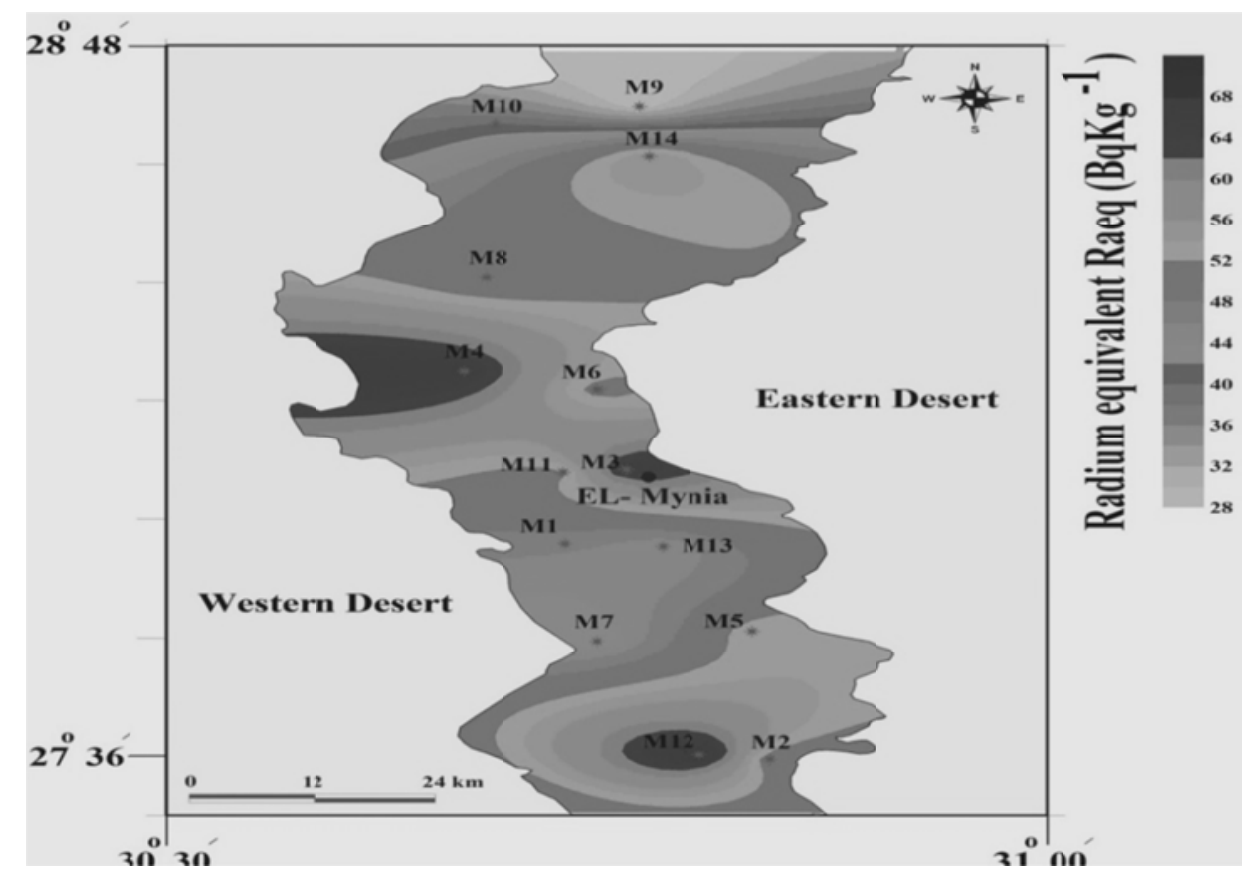

Figure 6: The distribution of radium equivalent activities $\left(\mathrm{Ra}_{\mathrm{eq}}\right)$ in agricultural soil. 


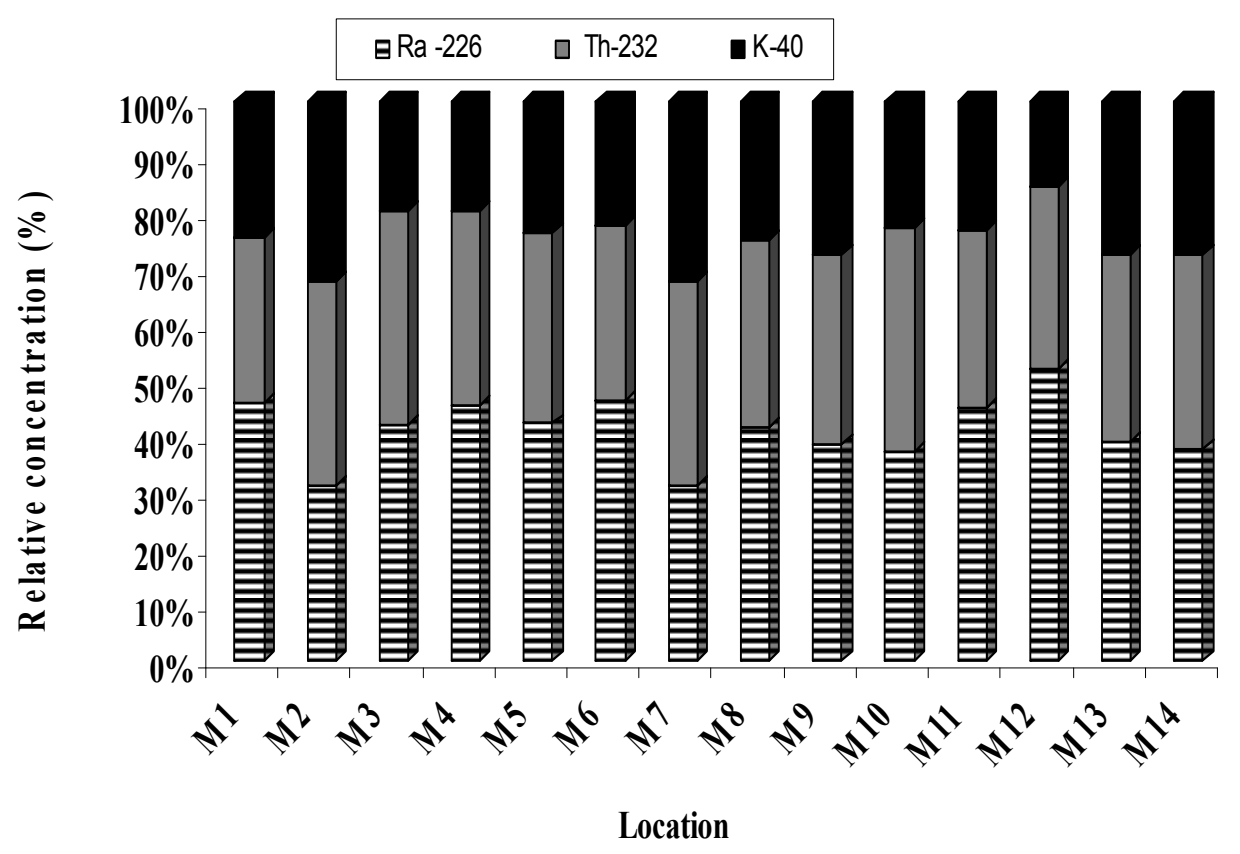

Figure 7: The relative contribution of ${ }^{226} \mathrm{Ra},{ }^{232} \mathrm{Th}$ and ${ }^{40} \mathrm{~K}$ to $\mathrm{Ra}_{\mathrm{eq}}$ in agricultural soil.

\subsubsection{Absorbed gamma dose rate (D)}

The absorbed dose rates due to gamma radiation in the air at $1 \mathrm{~m}$ above the ground surface for the uniform distribution of the naturally occurring radionuclides $\left({ }^{226} \mathrm{Ra},{ }^{232} \mathrm{Th}\right.$ and $\left.{ }^{40} \mathrm{~K}\right)$ were calculated based on guidelines provided by The United Nations Scientific Committee on the Effects of Atomic Radiation (UNSCEAR). ${ }^{18}$

The conversion factors used to compute the absorbed gamma dose rate (D) in air per unit activity concentration ${ }^{19}$ in $\mathrm{Bq} \mathrm{kg}^{-1}$ (dry weight) corresponds to $0.462 \mathrm{nGy}$ $\mathrm{h}^{-1}$ for ${ }^{226} \mathrm{Ra}, 0.604 \mathrm{nGy} \mathrm{h}^{-1}$ for ${ }^{232} \mathrm{Th}$ and $0.042 \mathrm{nGy} \mathrm{h}^{-1}$ for ${ }^{40} \mathrm{~K}$. Therefore, D can be calculated as follows:

$$
\mathrm{D}=0.462 \mathrm{~A}_{\mathrm{Ra}}+0.604 \mathrm{~A}_{\mathrm{Th}}+0.0417 \mathrm{~A}_{\mathrm{K}}
$$

where $A_{R a}, A_{T h}$ and $A_{K}$ have the same meaning as in Equation 1.

The average absorbed dose rates in Table 3 for ${ }^{226} \mathrm{Ra},{ }^{232} \mathrm{Th}$ and ${ }^{40} \mathrm{~K}$ in agricultural soil samples ranged from 13.3 to $31.9 \mathrm{nGy} \mathrm{h}^{-1}$. These values are below the allowed maximum value ${ }^{12}$ of $59 \mathrm{nGy} \mathrm{h}^{-1}$. 


\subsubsection{Annual effective dose (AED)}

The annual effective dose rate outdoors, in units of $\mu \mathrm{Sv}^{-1}$, is calculated by the following formula: ${ }^{20}$

$$
\text { Annual effective dose }(\mathrm{AED}) \text { rate }=\mathrm{D} \times \mathrm{T} \times \mathrm{F}
$$

where $\mathrm{D}=$ the calculated dose rate in $\mathrm{nGy} \mathrm{h}^{-1}, \mathrm{~T}=$ the outdoor occupancy time $\left(0.2 \times 24 \mathrm{~h} \times 365.25 \mathrm{~d} \approx 1753 \mathrm{~h} \mathrm{y}^{-1}\right)$, and $\mathrm{F}=$ the conversion factor $\left(0.7 \times 10^{-6}\right.$ $\left.\mathrm{SvG} \mathrm{y}^{-1}\right)$.

The AED rates vary from 16.3 to $39.2 \mu \mathrm{Sv} \mathrm{y}^{-1}$. These values are lower than the world average values ${ }^{21}$ at $70 \mu \mathrm{Sv} \mathrm{y}^{-1}$, as shown in Table 3, column 4 . The relative contribution of radium to the absorbed dose and AED are higher than the relative contributions of both thorium and potassium, as shown in Figure 8. Figure 9 shows the distributions of dose rate and AED for agricultural soil.

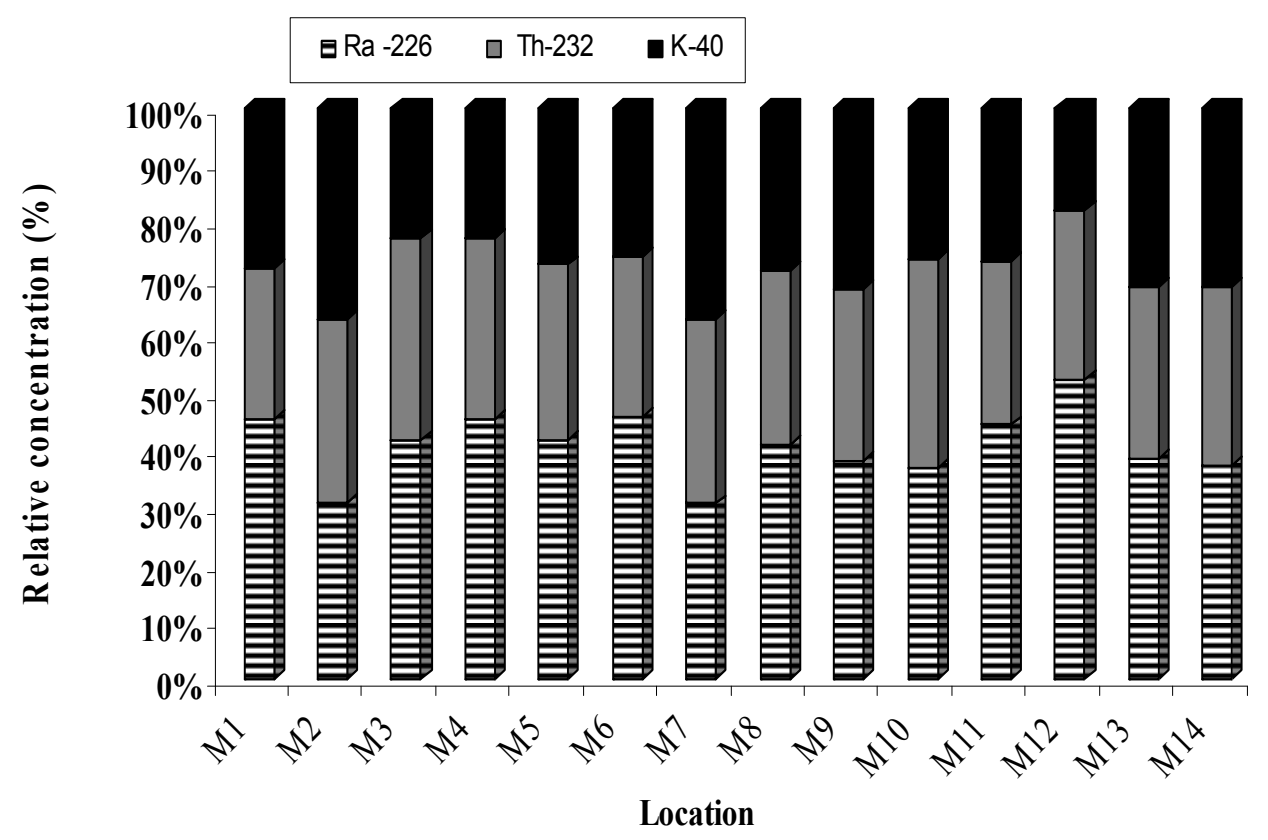

Figure 8: The relative contribution of ${ }^{226} \mathrm{Ra},{ }^{232} \mathrm{Th}$ and ${ }^{40} \mathrm{~K}$ to dose rate and AED in agricultural soil. 


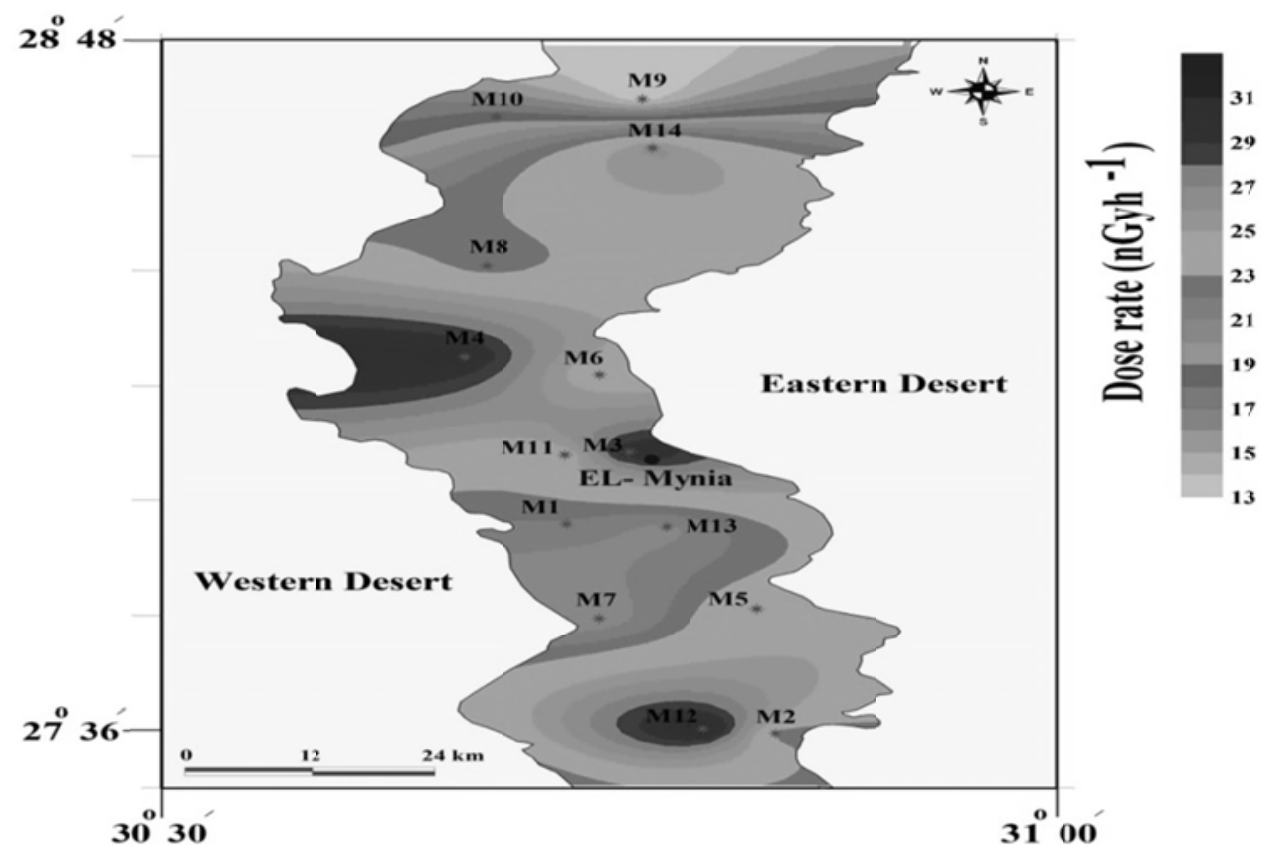

Figure 9: The distribution of dose rate and AED for agricultural soil.

\subsubsection{External hazard index $\left(\mathrm{H}_{\mathrm{ex}}\right)$}

The external hazard index $\left(\mathrm{H}_{\mathrm{ex}}\right)$ was determined from the following criterion formula: ${ }^{22}$

$$
H e x=\frac{C_{R a}}{370}+\frac{C_{T h}}{259}+\frac{C_{K}}{4180} \leq 1
$$

where $\mathrm{C}_{\mathrm{Ra}}, \mathrm{C}_{\mathrm{Th}}$ and $\mathrm{C}_{\mathrm{K}}$ are the activities of ${ }^{226} \mathrm{Ra},{ }^{232} \mathrm{Th}$ and ${ }^{40} \mathrm{~K}$, respectively, in $\mathrm{Bq} \mathrm{kg}{ }^{-1}$.

Table 3 (column 5) shows that, the calculated external hazard values resulting from all samples are lower than unity ${ }^{12}$ and thus do not cause any harm to the farmers and populations in all regions under investigation. 


\subsubsection{Internal hazard index $\left(\mathrm{H}_{\text {in }}\right)$}

The internal hazard index $\left(\mathrm{H}_{\text {in }}\right)$ describes the internal exposure to carcinogenic radon and its short-lived progeny ${ }^{23}$ and is given by the following formula: ${ }^{17,21}$

$$
\mathrm{H}_{\text {in }}=\left(\mathrm{A}_{\mathrm{Ra}} / 185+\mathrm{A}_{\mathrm{Th}} / 259+\mathrm{A}_{\mathrm{K}} / 4810\right) \leq 1
$$

where $A_{R a}, A_{T h}$ and $A_{K}$ have the same meaning as in Equation 1 .

Table 3 shows that the calculated average values of the internal hazard index $\left(\mathrm{H}_{\text {in }}\right)$ for all samples are less than unity.

\subsubsection{Gamma radiation hazard index $\left(\mathbf{I}_{\gamma \mathrm{r}}\right)$}

Another radiation hazard index called the representative level index, $I_{\gamma \mathrm{r}}$, is defined by the following formula, ${ }^{24}$ where $A_{R a}, A_{T h}$ and $A_{K}$ have the same meaning as in Equation 1:

$$
\mathrm{I}_{\gamma \mathrm{r}}=0.0067 \mathrm{~A}_{\mathrm{Ra}}+0.01 \mathrm{~A}_{\mathrm{Th}}+0.00067 \mathrm{~A}_{\mathrm{K}}
$$

The calculated $I_{\gamma \mathrm{r}}$ values for the samples under investigation are given in Table 4 . It is clear that the agricultural soil samples have results lower than unity. ${ }^{18}$ Figure 10 shows the relative contributions of ${ }^{226} \mathrm{Ra},{ }^{232} \mathrm{Th}$ and ${ }^{40} \mathrm{~K}$ to $\mathrm{I}_{\gamma \mathrm{r}}$ in agricultural soil, while Figure 11 shows the distribution of the representative level index $\mathrm{I}_{\gamma}$.

Table 4: Gamma radiation hazard index $\left(\mathrm{I}_{\mathrm{\gamma r}}\right)$, excess lifetime cancer risk (ELCR) and annual gonadal dose equivalent (AGDE) for agricultural soil.

\begin{tabular}{cccc}
\hline Location code & $\mathrm{I} \gamma$ & ELCR & $\begin{array}{c}\mathrm{AGDE} \\
\left(\mu \mathrm{Sv} \mathrm{y}{ }^{-1}\right)\end{array}$ \\
\hline M1 & $0.34^{*}$ & $9.41 \mathrm{E}-05$ & 154.2 \\
M2 & $(0.314-0.371)$ & $(8.75 \mathrm{E}-05-1.03 \mathrm{E}-04)$ & $(143.5-167.8)$ \\
& 0.35 & $9.60 \mathrm{E}-05$ & 157.8 \\
M3 & $(0.279-0.435)$ & $(9.34 \mathrm{E}-05-1.18 \mathrm{E}-04)$ & $(126.3-193.6)$ \\
& 0.478 & $1.31 \mathrm{E}-04$ & 214.6 \\
M4 & $0.424-0.538)$ & $(1.17 \mathrm{E}-04-1.48 \mathrm{E}-04)$ & $(191.5-242)$ \\
& 0.477 & $1.31 \mathrm{E}-04$ & 214.6 \\
M5 & $(0.397-0.546)$ & $(1.08 \mathrm{E}-04-1.50 \mathrm{E}-04)$ & $(178-245.5)$ \\
& 0.387 & $1.07 \mathrm{E}-04$ & 174.9 \\
& $(0.319-0.463)$ & $(8.70 \mathrm{E}-05-1.28 \mathrm{E}-04)$ & $(143.7-208.9)$ \\
\hline
\end{tabular}

(continued on next page) 
Table 4: (Continued)

\begin{tabular}{cccc}
\hline M6 & 0.364 & $1.01 \mathrm{E}-04$ & 164.7 \\
& $(0.318-0.432)$ & $(8.71 \mathrm{E}-05-1.20 \mathrm{E}-04)$ & $(143.2-195.6)$ \\
M7 & 0.313 & $8.55 \mathrm{E}-05$ & 141.5 \\
& $(0.293-0.347)$ & $(8.03 \mathrm{E}-05-9.45 \mathrm{E}-05)$ & $(132.7-156.3)$ \\
M8 & 0.348 & $9.55 \mathrm{E}-05$ & 157 \\
& $(0.261-0.438)$ & $(7.14 \mathrm{E}-05-1.21 \mathrm{E}-04)$ & $(118-197.8)$ \\
M9 & 0.207 & $5.69 \mathrm{E}-05$ & 93.7 \\
& $(0.195-0.220)$ & $(5.38 \mathrm{E}-05-6.06 \mathrm{E}-05)$ & $88.4-99.8$ \\
M10 & 0.292 & $8.00 \mathrm{E}-05$ & 131.7 \\
& $(0.259-0.338)$ & $(7.07 \mathrm{E}-05-9.24 \mathrm{E}-05)$ & $(116.7-151.3)$ \\
M11 & 0.363 & $1.01 \mathrm{E}-04$ & 164 \\
& $(0.305-0.475)$ & $(8.46 \mathrm{E}-05-1.32 \mathrm{E}-04)$ & $(151.5-182.6)$ \\
M12 & 0.496 & $1.37 \mathrm{E}-04$ & 223.4 \\
& $0.481-0.517$ & $(1.34 \mathrm{E}-04-1.43 \mathrm{E}-04)$ & $(217.4-232.6)$ \\
M13 & 0.321 & $8.81 \mathrm{E}-05$ & 145 \\
& $(0.278-0.373)$ & $(7.66 \mathrm{E}-05-9.99 \mathrm{E}-05)$ & $(126.4-165.6)$ \\
M14 & 0.414 & $1.13 \mathrm{E}-04$ & 186.6 \\
& $(0.403-0.425)$ & $(1.09 \mathrm{E}-04-1.17 \mathrm{E}-04)$ & $(180.6-192.5)$ \\
\hline
\end{tabular}

${ }^{*}$ Mean, (range)

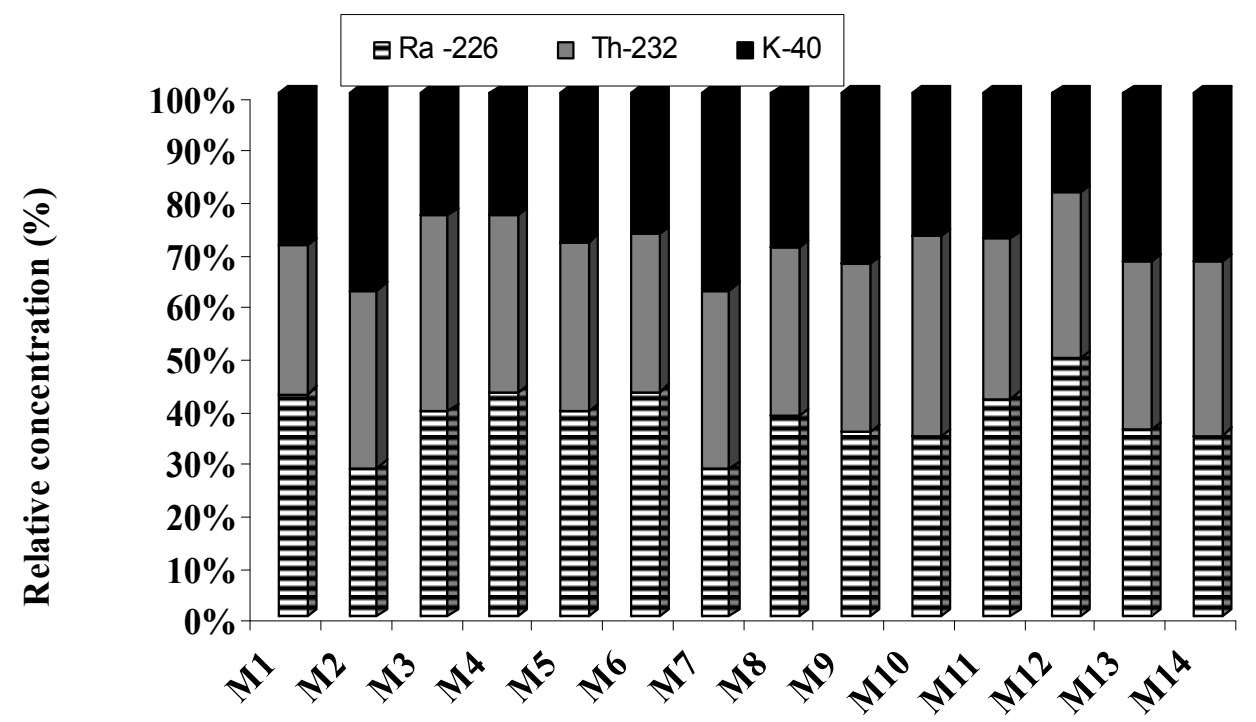

\section{Location}

Figure 10: The relative contribution of ${ }^{226} \mathrm{Ra},{ }^{232} \mathrm{Th}$ and ${ }^{40} \mathrm{~K}$ to $\mathrm{I}_{\gamma \mathrm{r}}$ in agricultural soil. 


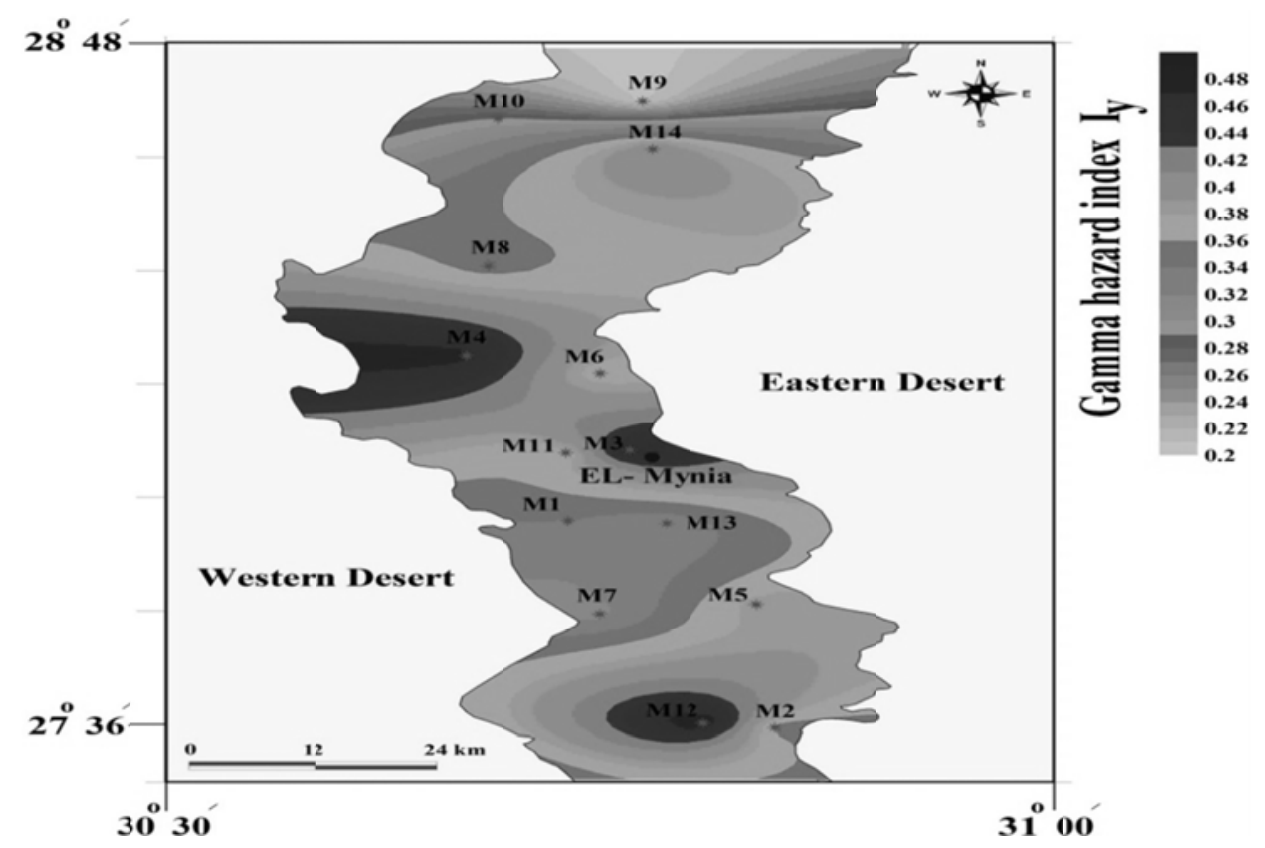

Figure 11: The distribution of $\mathrm{I}_{\gamma \mathrm{r}}$ for agricultural soil samples.

\subsubsection{Excess lifetime cancer risk (ELCR)}

Excess lifetime cancer risk (ELCR) was calculated using the following equation: ${ }^{25}$

$$
\mathrm{ELCR}=\mathrm{EDR} \times \mathrm{DL} \times \mathrm{RF}
$$

where

$\mathrm{EDR}=$ the annual effective dose equivalent, $\mathrm{DL}=$ duration of life $(30-70$ years $)$, and RF is a risk factor: $\left(\mathrm{Sv}^{-1}\right)$ fatal cancer risk per Sievert. For stochastic effects, ICRP 60 uses values of $(R F=0.05)$ in public.

From Table 4, the calculated value of ELCR showed that the highest average excess lifetime cancer risk (ELCR) is 1.37E-04 in samples from location (12), due to the use of mixed fertiliser (nitrogen-phosphorus). 


\subsubsection{Annual gonadal dose equivalent (AGDE)}

According to UNSCEAR, ${ }^{26}$ the gonads, active bone marrow and bone surface cells are considered the organs of interest. Therefore, the annual gonadal dose equivalent (AGDE, $\mu \mathrm{Sv} \mathrm{y}^{-1}$ ) due to the specific activities of ${ }^{226} \mathrm{Ra},{ }^{232} \mathrm{Th}$ and ${ }^{40} \mathrm{~K}$ for farmers was calculated using the following formula, ${ }^{27}$ where $A_{R a}, A_{T h}$ and $A_{K}$ have the same meaning as in Equation 1:

$$
\mathrm{AGDE}=3.09 \mathrm{~A}_{\mathrm{Ra}}+4.18 \mathrm{~A}_{\mathrm{Th}} \quad 0.314 \mathrm{~A}_{\mathrm{K}}
$$

The average values of AGDE are presented in Table 4 (column 4). As shown, the highest average value is $223.4\left(\mu \mathrm{Sv} \mathrm{y}^{-1}\right)$ in samples from location (12), which is attributable to the use of mixed fertiliser (nitrogen- phosphorus).

\subsection{Effective Dose due to Ingestion (M)}

The annual effective dose from the consumption of maize was calculated using the following formula: ${ }^{12}$

$$
\mathrm{M}=\mathrm{AEI}
$$

where

$\mathrm{M}=$ the annual effective dose $\left(\mathrm{Sv}^{-1}\right)$

$\mathrm{A}=$ the activity concentration for the radionuclide $\left(\mathrm{Bq} \mathrm{kg}^{-1}\right)$

$\mathrm{E}=$ the dose conversion factor for the radionuclide $\left(\mathrm{Sv} \mathrm{Bq}^{-1}\right)$

$\mathrm{I}=$ the annual intake of maize $(\mathrm{kg})$

The values for $\mathrm{E}\left(0.28,0.23\right.$ and $0.0062 \mu \mathrm{Sv} \mathrm{Bq}^{-1}$ for ${ }^{226} \mathrm{Ra},{ }^{232} \mathrm{Th}$ and ${ }^{40} \mathrm{~K}$, respectively) were selected based on the International Commission on Radiological Protection (ICRP) classifications for adults. ${ }^{28}$ The values of I were taken to be $67.3 \mathrm{~kg} \mathrm{y}^{-1}$, according to the Egyptian Ministry of Agriculture and Land Reclamation Report (2013) $)^{5}$. The results of the annual effective dose $\mathrm{M}$ are presented in Table 3.

Table 5 shows that the values of the annual effective dose $\left(\mu \mathrm{Sv} \mathrm{y}^{-1}\right)$ from the consumption of maize by adults were found to be of several orders of magnitude higher than the $290 \mu \mathrm{Sv} \mathrm{y}^{-1}$ world average of ingestion exposure from natural sources reported in UNSCEAR (2000), ${ }^{12}$ except for $254.4 \mu \mathrm{Sv}^{-1}$ in the samples from location M1. 
Table 5: Annual effective dose $\left(\mu \mathrm{Sv}^{-1}\right)$ from consumption of maize for adults.

\begin{tabular}{ccccc}
\hline \multirow{2}{*}{$\begin{array}{c}\text { Sampling } \\
\text { location }\end{array}$} & \multicolumn{2}{c}{$\begin{array}{c}\text { AED }\left(\mu \mathrm{Sv} \mathrm{y}^{-1}\right) \text { from consumption } \\
\text { of maize for the adult }\end{array}$} & $\begin{array}{c}\text { Total } \\
\left(\mu \mathrm{Sv} \mathrm{y}^{-1}\right)\end{array}$ \\
\cline { 2 - 3 } & ${ }^{226} \mathrm{Ra}$ & ${ }^{232} \mathrm{Th}$ & ${ }^{40} \mathrm{~K}$ & \\
\hline M1 & 101.8 & 88.2 & 64.4 & 254.4 \\
M2 & 182.8 & 134.7 & 72.8 & 390 \\
M3 & 226.1 & 92.9 & 86.8 & 405.8 \\
M4 & 179.3 & 145.5 & 89.9 & 406 \\
M5 & 163.9 & 150.1 & 75.8 & 389.9 \\
M6 & 220.5 & 77.4 & 86.8 & 384.7 \\
M7 & 201.3 & 123.8 & 89.7 & 415.8 \\
M8 & 150.8 & 99.1 & 71.5 & 321.3 \\
M9 & 158.3 & 128.5 & 97.4 & 384 \\
M10 & 188.4 & 161 & 89 & 438.5 \\
M11 & 258.2 & 170.3 & 83 & 511.5 \\
M12 & 220.5 & 119.2 & 68.4 & 408.1 \\
M13 & 182.8 & 88.2 & 72.8 & 343.8 \\
M14 & 235.7 & 131.6 & 84.3 & 451 \\
\hline
\end{tabular}

The average activity concentrations $\left(\mathrm{Bqkg}^{-1}\right)$ of ${ }^{226} \mathrm{Ra},{ }^{232} \mathrm{Th}$ and ${ }^{40} \mathrm{~K}$ in the agricultural soil and maize samples of this work are compared with other studies in (Table 6), which shows that the mean values of ${ }^{226} \mathrm{Ra},{ }^{232} \mathrm{Th}$ and ${ }^{40} \mathrm{~K}$ in soil and maize were in near or less than the corresponding values in the listed countries.

Table 6: Comparison of the average activity concentrations in the present study and from different studies.

\begin{tabular}{lcccc}
\hline \multirow{2}{*}{ Country } & Samples & \multicolumn{3}{c}{ Activity $\left(\mathrm{Bq} \mathrm{kg}^{-1}\right)$} \\
\cline { 3 - 5 } & & ${ }^{226} \mathrm{Ra}$ & ${ }^{232} \mathrm{Th}$ & ${ }^{40} \mathrm{~K}$ \\
\hline Egypt (EL-Mynia): & Agricultural soil & 21 & 12.1 & 154.4 \\
Present work & & & & \\
UNSCEAR $^{12}$ & Soil & $5-180$ & $2-140$ & $66-1150$ \\
Egypt (Alexandria) $^{29}$ & Agricultural soil & 16.43 & 18.31 & 268.16 \\
Jordan $^{30}$ & Ma'an soil & 57.7 & 18.1 & 138.1 \\
Egypt (Qena) $^{31}$ & Farm soil & 13.7 & 12.3 & 1233 \\
Niger (Jos Plateau) $^{13}$ & Farm soil & $\mathrm{NM}$ & 734 & 115.8 \\
Egypt (El-Qattamia) $^{32}$ & Soil & 23.66 & 13.95 & 146.33 \\
Yugoslavia (Vojvodina) $^{33}$ & Agricultural soil & 39.3 & 53 & 454 \\
Algeria $^{34}$ & Fertilised soil & 53.2 & 50.03 & 311 \\
\hline & & & &
\end{tabular}


Table 6 (Continued)

\begin{tabular}{|c|c|c|c|c|}
\hline Pakistan(Pakka Anna) $)^{35}$ & Fertilised soil & $30-38$ & $50-64$ & $560-635$ \\
\hline Brazil (Panama) ${ }^{36}$ & Fertilised soil & 10.22 & 7.27 & 54.75 \\
\hline Egypt (Aswan) $)^{37}$ & Agricultural soil & 16.92 & 21.96 & 505.92 \\
\hline Stromboli ${ }^{38}$ & Soil & NM & 68 & 454 \\
\hline India $^{39}$ & Soil & NM & 104 & 217 \\
\hline Egypt (Southeastern) ${ }^{40}$ & Soil & NM & $1.86-10$ & $292-659$ \\
\hline Egypt (Abou Zabal region) ${ }^{41}$ & Cultivated soil & 31.12 & 10.96 & 264.1 \\
\hline $\begin{array}{l}\text { Egypt (EL-Mynia): } \\
\text { Present work }\end{array}$ & Maize & 10.2 & 7.9 & 200 \\
\hline Niger (Jos Plateau) $)^{13}$ & Maize & NM & BDL & 243.2 \\
\hline Turkey $^{42}$ & Maize & 25.82 & BDL & 491.62 \\
\hline Brazil (Bernambuco) $)^{43}$ & Maize & 0.07 & NM & NM \\
\hline U.S.A (New York) ${ }^{43}$ & Maize & 56.8 & NM & NM \\
\hline
\end{tabular}

\section{CONCLUSION}

The activity concentrations of naturally occurring radionuclides in soil samples from all studied locations were below the world average ranges of 35, 35 and 370 $\mathrm{Bq} \mathrm{kg}{ }^{-1}$ for ${ }^{226} \mathrm{Ra},{ }^{232} \mathrm{Th}$ and ${ }^{40} \mathrm{~K}$, respectively, ${ }^{12}$ except for one location (M12), in which the activity concentration of ${ }^{226} \mathrm{Ra}$ is slightly higher, at $37 \mathrm{~Bq} \mathrm{~kg}^{-1}$. The radiological hazards for all soil samples were lower than the world average, so it is safe for farmers and the population and can be used to build raw materials or other human activities without any radiological risk.

The TFs for ${ }^{226} \mathrm{Ra},{ }^{232} \mathrm{Th}$ and ${ }^{40} \mathrm{~K}$ from soil to maize are higher than the default values of $0.04,0.05$ and 1 for ${ }^{226} \mathrm{Ra},{ }^{232} \mathrm{Th}$ and ${ }^{40} \mathrm{~K}$, respectively. ${ }^{15}$ The annual effective dose from the consumption of maize was calculated for adults and found to be of several orders of magnitude higher than the $0.29 \mathrm{mSv} \mathrm{y}^{-1}$ world average ingestion exposure from natural sources reported in UNSCEAR (2000). ${ }^{12}$

\section{ACKNOWLEDGEMENT}

This work was carried out using the nuclear analytical facilities at Physics Department, Faculty of Sciences, Al-Azhar University, Assiut, Egypt. 


\section{REFERENCES}

1. Shams, A. M. et al. (2014). A comparative study of the radiological hazard in sediments samples from drinking water purification plants supplied from different sources. J. Rad. Res. Appl. Sci., 7, 80-94, http://dx.doi.org/10.1016/j.jrras.2013.12.006.

2. Salahel Din, K. (2011). Determination of ${ }^{210} \mathrm{Po}$ in various foodstuffs and its annual effective dose to inhabitants of Qena City, Egypt. Sci. Total Environ., 409, 5301-5304, http://dx.doi.org/10.1016/j.scitotenv.2011. 09.001 .

3. Al-Masri, M. S. et al. (2008). Transfer of ${ }^{40} \mathrm{~K},{ }^{238} \mathrm{U},{ }^{210} \mathrm{~Pb}$, and ${ }^{210} \mathrm{Po}$ from soil to plant in various locations in south of Syria. J. Environ. Radioact., 99, 322-331, http://dx.doi.org/10.1016/j.jenvrad.2007.08.021.

4. Issa, S., Uosif, M. \& Elsaman, R. (2013). Gamma radioactivity measurements in Nile River sediment samples. Turkish J. Eng. Env. Sci., 37, 109-122, http://dx.doi.org/10.3906/muh-1207-21.

5. Ministry of Agriculture and Land Reclamation. (2013). Study of food balance sheet, various issues. Report by Economic Affairs Sector, Central Administration of Agricultural Planning, Cairo, Egypt.

6. International Atomic Energy Agency, IAEA. (1989). Measurements of radionuclides in food and the environment. Vienna: IAEA.

7. Issa, S. A. M., Mostafa, A. M. A. \& Abd El-Salam, M. L. (2015). Radiological impacts of natural radioactivity in phosphate rocks from ElSibaiya and Red Sea coast mines, Egypt. J. Radioanal. Nucl. Chem., 303, 53-61, http://dx.doi.org/10.1007/s10967-014-3312-x.

8. Uosif, M. A. M. (2014). Estimation of radiological hazards of some egyptian building materials due to natural radioactivity. Int. J. u-e-Serv. Sci. Technol., 2, 63-76, http://dx.doi.org/10.14257/ijunesst.2014.7.2.06.

9. GENIE-2000. (1997). Basic spectroscopy (standalone) V1.2A. Canberra: Canberra Industries.

10. Uosif, M. A. M. (2007). Gamma-ray spectroscopic analysis of selected samples of Nile river sediments in Upper Egypt. Radiat. Prot. Dosim., 123(2), 215-220, http://dx.doi.org/10.1093/rpd/ncl103.

11. Bhatti, T. M. \& Malik, K. A. (1994). Phosphate fertilizers as a potential source for uranium recovery as by product: A technical report. National Institute for Biotechnology and Genetic Engineering (NIBGE), Faisalabad.

12. United Nations Scientific Committee on the Effects of Atomic Radiation, UNSCEAR. (2000). Sources, effects and risks of ionizing radiation. Report to the General Assembly with annex B, United Nations, New York. 
13. Jibiri, N. N., Farai, I. P. \& Alausa, S. K. (2007). Estimation of annual effective dose due to natural radioactive elements in ingestion of foodstuffs in tin mining area of Jos-Plateau, Nigeria. J. Environ. Radioact., 94(1), 31-40, http://dx.doi.org/10.1016/j.jenvrad.2006.12.011.

14. Al-Kharouf, S. J., Al-Hamarneh, I. F. \& Dababneh, M. (2008). Natural radioactivity, dose assessment and uranium uptake by agricultural crops at Khan Al-Zabeeb, Jordan. J. Environ. Radioact., 99, 1192-1199, http://dx.doi.org/10.1016/j.jenvrad.2008.02.001.

15. IAEA. (1994). Handbook of parameter values for the prediction of radionuclide transfer in temperate environments. Vienna: IAEA.

16. Camacho, A. et al. (2010). Distribution of uranium isotopes in surface water of the Llobregat river basin (Northeast Spain). J. Environ. Radioact., 101, 1048-1054, http://dx.doi.org/10.1016/j.jenvrad.2010. 08.005 .

17. Beretka, J. \& Mathew, P. J. (1985). Natural radioactivity of Australian building materials, industrial wastes and by-products. Health Phys., 48(1), 87-95.

18. Palomo, M. et al. (2010). Presence of naturally occurring radioactive materials in sludge samples from several Spanish water treatment plants. J. Hazard. Mater., 716-720, http://dx.doi.org/10.1016/j.jhazmat.2010. 05.071 .

19. Ross, K. \& Riaz, A. (2008). Naturally occurring radionuclides in materials derived from urban water treatment plants in southeast Queensland, Australia. J. Environ. Radioact., 99(4), 607-620, http://dx.doi.org/10.1016/j.jenvrad.2007.09.001.

20. UNSCEAR. (1993). Sources and effects of ionizing radiation. Report to General Assembly, with Scientific Annexes, United Nations, New York.

21. Örgün, Y. et al. (2007). Natural and anthropogenic radionuclides in rocks and beach sands from Ezine region (Çanakkale), Western Anatolia, Turkey. App. Radiat. Isot., 65, 739-747, http://dx.doi.org/10.1016/ j.apradiso.2006.06.011.

22. Hayambu, P. et al. (1995). Natural radioactivity in Zambian building materials collected from Lusaka. J. Radioanal. Nucl. Chem., 199(3), 229-238, http://dx.doi.org/10.1007/BF02162371.

23. Ramasamy, V. et al. (2011). Horizontal and vertical characterization of radionuclides and minerals in river sediments. App. Radiat. Isot., 69, 184-195, http://dx.doi.org/10.1016/j.apradiso.2010.07.020.

24. Nuclear Energy Agency. (1979). Exposure to radiation from natural radioactivity in building materials. Report by NEA Group of Experts Organisation for Economic Co-operation and Development (OECD), Paris. 
25. International Commission on Radiological Protection. (1991). Recommendations of the International Commission on radiological protection. Annals of the ICRP, 21, 1-3.

26. UNSCEAR. (1982). Ionizing radiation: Sources and biological effects. Report to the General Assembly, United Nations, New York.

27. Mamont-Ciesla, K. et al. (1982). Radioactivity of building materials in Poland. In Vohra, G. et al. (Eds). Natural radiation environment. New York: Halsted Press.

28. International Commission on Radiological Protection, ICRP. (1996). Age-dependant doses to members of the public from intake of radionuclides, ICRP publication no. 72.

29. Saleh, H. (2007). Radiological study on soils, foodstuff and fertilizers in the Alexandria Region, Egypt. Turkish J. Eng. Env. Sci., 31, 9 - 17.

30. Saleh, H. \& Abu Shayeb, M. (2014). Natural radioactivity distribution of southern part of Jordan (Ma'an) Soil. Ann. Nucl. Energy, 65, 184-189, http://dx.doi.org/10.1016/j.anucene.2013.10.042.

31. Ahmed, N. K. \& El-Arabi, A. G. M. (2005). Natural radioactivity in farm soil and phosphate fertilizer and its environmental implications in Qena governorate, Upper Egypt. J. Environ. Radioact., 84, 51-64, http://dx.doi.org/10.1016/j.jenvrad.2005.04.007.

32. Nada, A. et al. (2009). Distribution of radionuclides in soil samples from a petrified wood forest in El-Qattamia, Cairo, Egypt. App. Radiat. Isot., 67, 643-649, http://dx.doi.org/10.1016/j.apradiso.2008.11.016.

33. Bikit, I. et al. (2005). Radioactivity of the soil in Vojvodina (northern province of Serbia and Montenegro). J. Environ. Radioact., 78, 11-19, http://dx.doi.org/10.1016/j.jenvrad.2004.03.034.

34. Boukhenfouf, W. \& Boucenna, A. (2011). The radioactivity measurements in soils and fertilizers using gamma spectrometry technique. J. Environ. Radioact., 102, 336-339, http://dx.doi.org/ 10.1016/j.jenvrad.2011.01.006.

35. Akhtar, N. et al. (2005). Measurement of environmental radioactivity for estimation of radiation exposure from saline soil of Lahore, Pakistan. Radiat. Meas., 39, 11-14, http://dx.doi.org/10.1016/j.radmeas.2004. 02.016 .

36. Becegato, V. A., Ferreira, F. J. F \& Machado, W. C. P. (2008). Concentration of radioactive elements ( $\mathrm{U}, \mathrm{Th}$ and $\mathrm{K}$ ) derived from phosphatic fertilizers in cultivated soils. Braz. Arch. Biol. Technol., 51(6), 1255-1266, http://dx.doi.org/10.1590/S1516-89132008000 600022 .

37. Harb, S. et al. (2008). Radioactivity levels and soil-to-plant transfer factor of natural radionuclides from Protectorate area in Aswan, Egypt. Paper presented at the 38th Annual Conference of the Egyptian Society of Radiology \& Nuclear Medicine, Egypt, 23-24 October. 
38. Brai, M. et al. (2002). Environmental radioactivity at Stromboil (Aeolian Islands). Appl. Radiat. Isot., 57, 99-107.

39. Selvasekarapandian, S. et al. (2000). Natural radionuclide distribution in soils of Gudlaore, India. App. Radiat. Isot., 52, 299-306.

40. Sroor, A. et al. (2001). Natural radioactivity and radon exhalation rate of soil in southern Egypt. App. Radiat. Isot., 55, 873-879.

41. Diab, H. M. et al. (2008). Evaluation of natural radioactivity in a cultivated area around a fertilizer factory. J. Nucl. Radiat. Phys., 3(1), 53-62.

42. Bolca, M. et al. (2007). Radioactivity in soils and various foodstuffs from the Gediz River Basin of Turkey. Radiat. Meas., 42, 263-270, http://dx.doi.org/10.1016/j.radmeas.2006.12.001.

43. Amaral, R. S. et al. (2005). Intake of uranium and radium-226 due to food crops consumption in the phosphate region of Pernambuco - Brazil. J. Environ. Radioact., 82, 383-393, http://dx.doi.org/10.1016/ j.jenvrad.2005.02.013. 